\title{
Determinasi Profitabilitas Pada Perusahaan Manufaktur Sektor Barang Konsumsi
}

\section{Determination of Profitability in the Consumer Goods Manufacturing Company}

\author{
Evi Husnah*, Iwan Setiadi \\ Institut Teknologi Bisnis Ahmad Dahlan Jakarta, Indonesia
}

The purpose of this study is to analyze the effect of Current Ratio, Total Asset Turnover, Debt to Equity and Company Size on Profitability either partially or simultaneously. The design in this study is causal associative. The sample in this study included all Manufacturing Companies of the Consumer Goods Industry Sector Listed on the Indonesia Stock Exchange during 2011-2017. Sample selection techniques using purposive sampling method obtained as many as 20 companies that will be used as research objects. The test method is carried out by Descriptive Statistical Analysis, Classic assumption test consisting of normality test, auto correlation test, heteroscedasticity test and multicollinearity test, Multiple Linear Regression Test and Feasibility Test Model consisting of Determination Coefficient Test, T Test and F Test Results Partial shows that the Current Ratio has no effect on Return on Assets. Total Asset Turnover and company size have a positive and significant effect on Return on Assets, and Debt to Equity Ratio has a negative and significant effect on Return on Assets. But Simultaneously it is known that CR, TATO, DER and Size have significant effect on ROA. Adjust $R$ Square value of 0.268 , this

OPEN ACCESS ISSN 2548-3501 (online)

Edited by: Eny Maryanti

Reviewed by: Sigit Hermawan

*Correspondence:

Evi Husnah Husnah778@gmail.com

Received: 5 January 2020 Accepted: 23 January 2020 Published: 31 January 2020

Citation:

EH and IS (2020) Determinasi Profitabilitas Pada Perusahaan

Manufaktur Sektor Barang Konsumsi.

Journal of accounting Science. 4:1. doi: 10.21070/jas.v4i1.412 means that Return on Assets is influenced by Current Ratio, Total Asset Turnover, Debt to Equity and Company Size of $26.8 \%$ while the remaining $73.2 \%$ is influenced by other factors not examined in this study.

Keywords: Return on assets, Current Ratio, Total Asset Turnover, Debt to Equity Ratio, Company Size.

Tujuan dari penelitian ini adalah untuk menganalisa pengaruh Current Ratio (CR), Total Asset Turnover (TATO), Debt to Equity (DER) dan Ukuran Perusahaan (Size) terhadap Profitabilitas baik secara parsial maupun simultan. Desain dalam penelitian ini adalah asosiatif kausal. Sampel dalam penelitian ini meliputi seluruh Perusahaan Manufaktur Sektor Industri Barang Konsumsi yang Terdaftar di Bursa Efek Indonesia selama tahun 2011-2017. Teknik pemilihan sampel menggunakan metode purposive sampling diperoleh sebanyak 20 perusahaan yang dijadikan sebagai objek penelitian. Metode pengujian dilakukan dengan Analisis Statistik Deskriftif, Uji asumsi klasik yang terdiri dari uji normalitas, uji autokorelasi, uji heteroskedastisitas dan uji multikolonieritas, Uji Regresi Linier Berganda dan Uji Kelayakan Model yang terdiri dari Uji Koefisien Determinasi, Uji t dan Uji F. Hasil Penelitian secara parsial menunjukan bahwa Current Ratio tidak berpengaruh 
terhadap Return on Asset. Total Asset Turnover dan ukuran perusahaan berpengaruh positif dan signifikan terhadap Return on Asset, dan Debt to Equity Ratio berpengaruh negatif dan signifikan terhadap Return on Asset. Namun secara Simultan diketahui bahwa CR, TATO, DER dan Size berpengaruh signifikan terhadap ROA. Nilai Adjust R Square sebesar 0,268, hal ini berarti bahwa Return on Asset dipengaruhi oleh Current Ratio, Total Asset Turnover, Debt to Equity dan Ukuran Perusahaan sebesar 26,8\% sedangkan sisanya $73,2 \%$ dipengaruhi oleh faktor lain yang tidak diteliti dalam penelitian ini.

Keywords: Return on asset, Current Ratio, Total Asset Turnover, Debt to Equity Ratio, Ukuran Perusahaan. 


\section{PENDAHULUAN}

Pertumbuhan industri sektor barang konsumsi dapat menggambarkan persaingan bisnis yang kompetitif menuntut pelaku bisnis untuk mengelola perusahaan secara efektif dan efisien. Salah satu tujuan perusahaan yaitu mencapai keuntungan maksimal atau laba yang sebesar-besarnya. Salah satu upaya untuk mencapai tujuannya, perusahaan harus selalu berusaha memaksimalkan labanya sehingga dapat mencapai hasil dan tingkat laba yang optimal. Keberlangsungan hidup perusahaan dipengaruhi oleh banyak hal diantaranya yaitu profitabilitas perusahaan itu sendiri.

\section{[Figure 1 about here.]}

Sumber : www.Idnfinancials.com (data sekunder diolah 2019)

Berdasarkan Gambar 1 adapun fenomena yang terjadi pada perusahaan manufaktur sektor industri barang konsumsi yang terdaftar di BEI yaitu 2 perusahaan dengan pertumbuhan laba bersih yang mengalami penurunan selama 3 tahun dan mengalami fluktuasi diantara 20 perusahaan lainnya yaitu PT Wismilak Inti Makmur Tbk dan PT Akasha Wira International Tbk.

PT Wismilak Inti Makmur Tbk membukukan pertumbuhan laba bersih Rp 129,5 Milyar pada tahun 2011. Perusahaan berkode saham WIIM tersebut berhasil mengalami fluktuasi laba bersih dari Rp 77,3 Milyar pada tahun 2012 naik menjadi Rp 131 Milyar pada tahun 2015. Dan mengalami penurunan laba bersih Rp 106,3 Milyar pada tahun 2016 dan Rp 40,6 Milyar pada tahun 2017.

Posisi kedua PT Akasha Wira International Tbk. Perusahaan berkode saham ADES telah mencetak pertumbuhan laba bersih Rp 25,7 Milyar ditahun 2011 dan terjadi Peningkatan laba ditahun 2012 menjadi Rp 83,4 Milyar. Dan mengalami fluktuasi laba bersih Rp 55,7 Milyar ditahun 2013, 31 Milyar ditahun 2014 dan 32,8 Milyar ditahun 2015. Mengalami kenaikan laba bersih Rp 55,9 ditahun 2016 dan mengalami penurunan kembali Rp 38,2 ditahun 2017.

Profitabilitas perusahaan sangatlah penting karena untuk dapat melangsungkan kegiatan operasionalnya, suatu perusahaan harus selalu berada dalam keadaan menguntungkan agar dapat menarik modal dari luar. Jika perusahaan ingin tetap bertahan, maka perusahaan tentunya harus menghasilkan laba guna membiayai kegiatan operasionalnya karena pada umumnya perusahaan tidak akan dapat bertahan tanpa adanya kemampuan dalam menghasilkan laba. Dalam penelitian ini rasio profitabilitas yang digunakan adalah ROA. ( Wiratna, 2017)

Faktor pertama yang mempengaruhi profitabilitas adalah Current Ratio. (Agha (2014) menyatakan current ratio yang terlampau tinggi menandakan besarnya dana menganggur yang tidak digunakan secara optimal bagi kepentingan bisnis sehingga dapat menurunkan profitabilitas. Sedangkan menurut Faturohman (2015) Current ratio yang tinggi akan berpen- garuh negatif terhadap kemampuan memperoleh laba (profitabilitas), karena sebagai modal kerja tidak berputar atau mengalami pengganguran.

Faktor kedua yang mempengaruhi profitabilitas yaitu Total asset turnover ratio Menurut Brigham and Houston (2013) menyatakan bahwa jika rasio total asset turnover yang rendah menunjukan perusahaan tersebut tidak menghasilkan cukup penjualan jika dibandingkan dengan asetnya. Total asset turnover menunjukan efektivitas penggunaan seluruh harta perusahaan dalam rangka menghasilkan penjualan. Jika perputarannya lambat, menunjukan bahwa aktiva yang dimiliki terlalu besar dibandingkan dengan kemampuan untuk menjual. Semakin cepat tingkat perputaran asetnya, maka laba bersih yang dihasilkan akan semakin meningkat karena perusahaan sudah memanfaatkan aset tersebut untuk meningkatkan penjualan yang berpengaruh terhadap pendapatan. (Barus (2013)

Faktor ketiga yang mempengaruhi profitabilitas yaitu Debt Equity Ratio. Debt to Equity ratio sering digunakan para analisis dan investor untuk melihat seberapa besar hutang perusahaan jika dibandingkan ekuitas yang dimiliki oleh perushaan atau para pemegang saham. Semakin tinggi angka debt to equity ratio maka diasumsikan perusahaan memiliki resiko yang semakin tinggi terhadap likuiditas perusahaannya. Semakin tinggi debt to equty ratio maka banyak dana masuk dari pihak kreditor sehingga dana tersebut dapat digunakan untuk menghasilkan laba. (Sujarweni (2017)

Selain itu, ukuran perusahaan mempengaruhi profitabilitas perusahaan. T. and Mawardi (2016) menyatakan bahwa semakin besar aset suatu perusahaan maka laba yang akan didapat akan besar pula karena aset yang dimiliki digunakan oleh perusahaan untuk aktivitas operasional dengan tujuan memperoleh laba.

Beberapa penelitian mengenai faktor yang mempengaruhi profitabilitas pada perusahaan manufaktur menunjukan hasil yang berbeda - beda. Penelitian yang dilakukan oleh Putri (2018) menunjukan bahwa Current ratio berpengaruh secara signifikan terhadap Return on Asset. Sejalan dengan penelitian yang dilakukan oleh Setiawan (2015) menunjukan bahwa current ratio berpengaruh secara signifikan terhadap profitabilitas. Berbeda dengan penelitian yang dilakukan oleh Asiah (2010) menunjukan bahwa variabel current ratio tidak mempunyai pengaruh yang signifikan terhadap profitabilitas. Sejalan dengan penelitian yang dilakukan oleh Barus (2013) yang menunjukan bahwa current ratio tidak berpengaruh secara signifikan terhadap profitabilitas.

Penelitian yang dilakukan oleh Putri (2018) menunjukan bahwa Total sset turnover berpengaruh signifikan terhadap profitabilitas. Penelitian yang dilakukan Asiah (2010) menunjukan bahwa Total asset turnover berpengaruh positif terhadap profitabilitas. Berbeda dengan penelitian yang dilakukan oleh Sari (2014) menunjukan bahwa variabel Total asset turnover tidak berpengaruh pada profitabilitas.

Penelitian yang dilakukan oleh Wijayanto (2018) menunjukan bahwa variable Debt to equity ratio berpengaruh sig- 
nifikan terhadap return on asset. Sejalan dengan hasil penelitian yang dilakukan oleh Raharjo (2016) menunjukan bahwa Debt to equity ratio berpengaruh secara signifikan terhadap return on asset. Berbeda dengan penelitian yang dilakukan oleh Asiah (2010) sejalan dengan penelitian yang dilakukan oleh Barus (2013) menunjukan bahwa Debt to equity ratio tidak berpengaruh signifikan terhadap profitabilitas.

Penelitian yang dilakukan Barus (2013) menunjukan bahwa Ukuran perusahaan berpengaruh secara signifikan dan positif terhadap profitabilitas. Sejalan dengan hasil penelitian penelitian yang dilakukan oleh Yuniarta (2015) menunjukan bahwa ukuran perusahaan berpengaruh positif dan signifikan terhadap profitabilitas. Berbeda dengan penelitian yang dilakukan oleh Sari (2014) menunjukan bahwa Ukuran perusahaan tidak berpengaruh pada profitabilitas. Sejalan dengan penelitian yang dilakukan oleh Raharjo (2016) menunjukan bahwa ukuran perusahaan tidak berpengaruh signifikan terhadap profitabilitas.

Perbedaan penelitian ini dengan penelitian-penelitian sebelumnya adalah variabel dan sektor perusahaan atau objek penelitian yang diteliti. Peneliti menggunakan variabel Current ratio, Total asset turnover, Debt to equity ratio dan Ukuran perusahaan sebagai variabel independent dan variabel Return on asset sebagai variabel dependent. Sedangkan untuk objek penelitian, peneliti mengambil perusahaan manufaktur sektor industri barang konsumsi periode tahun 2011-2017.

Kontribusi dari penelitian ini diharapkan dapat memberikan tambahan ilmu pengetahuan dan referensi bagi peneliti selanjutnya sekaligus dapat menjadi informasi bagi investor dan dalam mempertimbangkan keputusan investasinya dengan memperhatikan profitabilitas perusahaan.

\section{Kerangka Pemikiran dan Hipotesis}

\section{Teori Sinyal (Signalling Theory)}

Brigham and Houston (2013) mengatakan bahwa signalling theory merupakan suatu perilaku manajemen perusahaan dalam memberi petunjuk untuk investor terkait pandangan manajemen pada prospek perusahaan untuk masa mendatang. Isyarat atau signal adalah tindakan yang diambil oleh manajemen perusahaan dimana manajemen mengetahui informasi yang lebih lengkap dan akurat mengenai internal perusahaan dan prospek perusahaan di masa depan dari pada pihak investor.

Rasio Lancar (Current Ratio) menurut Kasmir (2016) merupakan rasio untuk mengukur kemampuan perusahaan membayar kewajiban jangka pendek atau utang yang segera jatuh tempo pada saat ditagih secara keseluruhan. Semakin rendahnya nilai current ratio, maka akan mengindikasi ketidakmampuan perusahaan dalam memenuhi kewajiban jangka pendeknya, sehingga hal ini dapat mempengaruhi tingkat profitabilitas perusahaan, dimana perusahaan yang tidak mampu memenuhi kewajiban akan dikenai beban tambahan atas kewajiban (Barus (2013)

Total asset turnover merupakan rasio yang menunjukan tingkat efisiensi penggunaan keseluruhan aktiva perusahaan dalam menghasilkan volume penjualan tertentu, rasio yang menggambarkan perputaran aktiva diukur dari volume penjualan. Jadi, semakin besar rasio ini, semakin baik yang berarti aktiva dapat lebih cepat berputar dan meraih laba yang menunjukan semakin efisiensi penggunaan keseluruhan aktiva dalam menghasilkan penjualan (Wardiyah (2017)

Kasmir (2016), menyatakan bahwa debt to equity ratio merupakan rasio yang digunakan untuk menilai utang dengan ekuitas. Semakin tinggi angka debt to equity ratio maka diasumsikan perusahaan memiliki resiko yang semakin tinggi terhadap likuiditas perusahaannya. Semakin tinggi debt to equty ratio maka banyak dana masuk dari pihak kreditor sehingga dana tersebut dapat digunakan untuk menghasilkan laba. (Sujarweni (2017)

Ukuran perusahaan menurut Hartono (2010) adalah ukuran aktiva digunakan untuk mengukur besarnya perusahaan, banyaknya tenaga kerja dan lain sebagainya. Ukuran perusahaan dapat dilihat dari total nilai aset, berapa total nilai penjualan, nilai kapitalisasi pasar, banyaknya tenaga kerja dan lain sebagainya. T. and Mawardi (2016) menyatakan bahwa semakin besar aset suatu perusahaan maka laba yang akan didapat akan besar pula karena aset yang dimiliki digunakan oleh perusahaan untuk aktivitas operasional dengan tujuan memperoleh laba.

Penelitian yang dilakukan oleh Barus (2013) dengan hasil pengujian secara simultan menunjukan bahwa CR, TATO, DER, DR, Pertumbuhan Penjualan dan Ukuran Perusahaan berpengaruh signifikan terhadap ROA. Secara parsial hanya TATO, DER dan Ukuran Perusahaan yang berpengaruh signifikan terhadap ROA.

\section{Pengaruh Current ratio (CR) terhadap Return on Asset}

semakin tinggi tingkat current ratio, maka semakin baik pula posisi perusahaan dimata kreditur, oleh karena terdapat kemungkinan besar perusahaan dalam membayar kewajiban jangka pendeknya dalam waktu yang telah ditentukan.

Semakin rendahnya nilai current ratio, maka akan mengindikasi ketidakmampuan perusahaan dalam memenuhi kewajiban jangka pendeknya, sehingga hal ini dapat mempengaruhi tingkat profitabilitas perusahaan, dimana perusahaan yang tidak mampu memenuhi kewajiban akan dikenai beban tambahan atas kewajiban (Barus (2013)

\section{Pengaruh Total asset turnover (TATO) terhadap Return on Asset}

semakin tinggi total asset turnover berarti semakin efisien penggunaan keseluruhan aset dalam menghasilkan penjualan. Jumlah aset yang sama dapat memperbesar volume penjualan apabila total asset tiurnover ditingkatkan atau diperbesar, sehingga apabila volume penjualan besar dan laba yang diperoleh semakin tinggi. total aset turnover yang rendah mencerminkan bahwa terdapat beberapa aset yang kurang produktif. Hal ini akan menghambat penjualan. Meningkatkan rasio ini dapat dilakukan dengan meningkatkan penjualan dan 
menghentika aset yang kurang produktif.

Pengaruh Debt to equity ratio terhadap Return on Asset

Menurut Azhari (2016) semakin tinggi debt to equity ratio menunjukan semakin tinggi penggunaan hutang sebagai sumber pendanaan perusahaan. Hal ini dapat menimbulkan beban bunga yang juga menjadi cukup besar bagi perusahaan, hal ini menimbulkan laba perusahaan berkurang dan tentu saja hal ini membuat semakin kecil return on asset dalam perusahaan.

Menurut Meithasari (2017) rasio hutang yang tinggi akan meningkatkan ancaman kebangkrutan untuk sebuah perusahaan, sehingga hal ini menekankan perusahaan untuk menjadi lebih berhati-hati dan tidak menghambur-hamburkan uang para pemegang saham. Semakin tingginya Debt to Equity Ratio (DER), semakin besar risiko keuangan. Risiko keuangan ini dapat menunjukkan bahwa semakin besar biaya yang harus ditanggung perusahaan untuk memenuhi kewajiban yang dimilikinya.

\section{Asset}

Pengaruh Ukuran Perusahaan Terhadap Return on

Menurut Azhari (2016) semakin besar perusahaan maka akan semakin besar pula aset yang dimiliki, jika aset semakin besar maka dana yang digunakan juga semakin besar untuk operasional, dengan semakin besar operasional maka cenderung berdampak pada pendapatan juga akan semakin besar yang tentu di ikuti oleh pergerakan dari laba perusahaan. Pergerakan laba inilah yang pasti akan menggerakan return on asset perusahaan, oleh karena itu ukuran perusahaan berpengaruh terhadap return on asset.

\section{Kerangka Pemikiran}

Kerangka pemikiran dalam penelitian ini pada adalah:Gambar 2

[Figure 2 about here.]

\section{METODE}

\section{Jenis Penelitian dan Sumber Data}

Sugiyono (2016) Metode penelitian pada dasarnya merupakan cara ilmiah untuk mendapatkan data dengan tujuan dan kegunaan tertentu. Dalam penelitian ini peneliti menggunakan pendekatan kuantitatif, yaitu pendekatan yang menggunakan data yang berbentuk angka pada analisis statistik berupa data laporan keuangan dan laporan tahunan perusahaan manufaktur sektor industri barang konsumsi yang terdaftar di Bursa Efek Indonesia. Penelitian ini juga bersifat asosiatif kausal yaitu hubungan antara dua variabel atau lebih yang dapat menjelaskan gejala. (www.idx.co.id dan www.idnfinancials.com).

\section{Populasi dan Teknik Pengambilan Sampel}

Populasi yang digunakan dalam penelitian ini adalah perusahaan manufaktur sektor industri barang konsumsi yang terdaf- tar di Bursa Efek Indonesia periode 2011-2017. Pemilihan sampel dalam penelitian ini menggunakan metode purpossive sampling,

yang merupakan metode pemilihan sampel yang didasarkan pada beberapa kriteria-kriteria tertentu. Adapun kriteria-kriteria tersebut adalah:

1. Perusahaan Manufaktur Sektor Industri Barang Konsumsi yang terdaftar dan di BEI pada tahun 2011-2017,

2. Perusahaan manufaktur yang menerbitkan laporan keuangan secara lengkap selama periode penelitian tahun 20112017.

3. Perusahaan yang tidak mengalami kerugian selama periode penelitian tahun 2011 - 2017.

Jumlah sampel yang digunakan adalah 20 perusahaan manufaktur sektor industri barang konsumsi dengan periode pengamatan 7 tahun sehingga jumlah pengamatan penelitian ini adalah sebanyak 140 .

\section{Pengukuran Variabel \\ Return on Asset}

Menurut Kasmir (2016) ROA digunakan untuk menunjukan kemampuan perusahaan menghasilkan laba dengan menggunakan total aset yang dimiliki. Menurut Sudana (2011) menyatakan bahwa return on assets menunjukan kemampuan dengan menggunakan seluruh aktiva yang dimiliki untuk menghasilkan laba setelah pajak. Penghitungan ROA dengan menggunakan rumus sebagai berikut:

$$
R O A=(\text { Laba Bersih Setelah Pajak }) /(\text { Total Asset })
$$

\section{Current Ratio}

Subramanyam and Wild (2013) menyatakan bahwa current rasio menggambarkan kemampuan perusahaan dalam membayar kewajiban jangka pendeknya (hutang dan pinjaman) dengan menggunkan asset lancar (kas, piutang dan persediaan) yang dimilikinya. Penghitungan CR dengan menggunakan rumus sebagai berikut:

$$
C R=(\text { Asset Lancar }) /(H u \tan g \text { Lancar })
$$

\section{Total assets turnover}

Kasmir (2016) mengatakan bahwa total asset turnover merupakan rasio yang digunakan untuk mengukur perputaran semua aktiva yang dimiliki perusahaan dan mengukur berapa jumlah penjualan yang diperoleh dari tiap rupiah aktiva. Penghitungan TATO dengan menggunakan rumus sebagai berikut:

$$
\text { TATO }=(\text { Total Penjualan }) /(\text { Total Asset })
$$

\section{Debt to equity ratio}

Debt to equity ratio adalah perbandingan antara hutang-hutang dan ekuitas dalam pendanaan perusahaan dan menunjukan kemampuan modal sendiri, perusahaan untuk memenuhi 
keseluruhan kewajibannya (Sujarweni (2017) Perhitungan dengan menggunakan rumus sebagai berikut:

$$
D E R=(\text { Total Hutan } g) /(\text { Total Ekuitas })
$$

\section{Metode Analisis Data}

Untuk menguji pengaruh Current Ratio (CR), Total Asset Turnover (TATO), Debt to Equity Ratio (DER) dan Ukuran Perusahaan (Size) terhadap profitabilitas perusahaan digunakan analisis regresi linier berganda, dengan tingkat signifikansi 5\%. Untuk memenuhi syarat model regresi yang baik perlu dilakukan pengujian asumsi klasik yaitu uji normalitas, uji autokorelasi, uji heteroskedastisitas dan uji multikolinearitas dan dilakukan uji kelayakan model (Godness Of Fits).

\section{HASIL DAN PEMBAHASAN}

\section{Statistik Deskriftif}

[Figure 3 about here.]

Gambar 3 Menunjukan jumlah sampel yang digunakan dalam penelitian ini adalah sebanyak 20 sampel dan jangka waktu observasi selama 7 tahun maka $\mathrm{N}=140$. Dari hasil pengujian statistik pada tabel 3 dapat diketahui bahwa nilai minimum ROA yaitu 0,0022 . Sedangkan nilai maksimumnya yaitu 0,6572 .Variabel return on asset (ROA) mempunyai nilai ratarata (mean) 0,128212, artinya bahwa setiap Rp 1 aset perusahaan dapat menghasilkan Rp. 0,128212 laba. Dan standar deviasi atau sebaran jumlah data 0,1095982. Dimana nilai rata-rata (mean) lebih besar daripada nilai standar deviasi yaitu 0,1095982 yang artinya bahwa terdapat perbedaan data bervariasi antar perusahaan sampel.

Berdasarkan hasil pengujian statistik pada Gambar 3 dapat diketahui bahwa nilai Minimum CR yaitu 0,5139. Sedangkan nilai maksimumnya yaitu 11,7429 . Variabel Current ratio (CR) mempunyai nilai rata-rata (mean) 2,638806, artinya bahwa setiap Rp 1 hutang lancar dapat ditanggung $\mathrm{Rp}$ 2,638806 oleh aset lancar. Standar deviasi atau sebaran jumlah data 1,7325072. Dimana nilai rata-rata (mean) lebih besar daripada nilai standar devisiasi yaitu 1,7325072 yang artinya bahwa terdapat perbedaan data bervariasi antar perusahaan sampel.

Berdasarkan hasil pengujian statistik pada Gambar 3 . dapat diketahui bahwa nilai minimum TATO yaitu 0,5563. Sedangkan nilai maksimumnya yaitu 3,3974. Variabel Total asset turnover (TATO) mempunyai nilai rata-rata (mean) 1,388571, artinya bahwa setiap Rp 1 aset perusahaan dapat menghasilkan 1,388571 kali penjualan. Standar deviasi atau sebaran jumlah data 0,56472. Dimana nilai rata-rata (mean) lebih besar daripada nilai standar devisiasi yaitu 0,5646997 yang artinya bahwa terdapat perbedaan data bervariasi antar perusahaan sampel.

Berdasarkan hasil pengujian statistik padaGambar 3 dapat diketahui bahwa nilai minimum DER yaitu 0,1165 . Sedangkan nilai maksimumnya yaitu 2,4926 . Variabel Debt to equity ratio
(DER) mempunyai nilai rata-rata (mean) 0,808873 artinya bahwa dari setiap Rp 1 modal sendiri menjadi jaminan utang yang sebesar Rp 0,808873 yang dimiliki perusahaan tersebut. Dan standar deviasi atau sebaran jumlah data 0,52162. Dimana nilai rata-rata (mean) lebih besar daripada nilai standar deviasi yaitu 0,56472 yang artinya bahwa terdapat perbedaan data bervariasi antar perusahaan sampel.

Berdasarkan hasil pengujian statistik pada Gambar 3 dapat diketahui bahwa nilai minimum SIZE yaitu 5,0720. Sedangkan nilai maksimumnya yaitu 7,9830. Variabel Ukuran Perusahaan (Size) mempunyai nilai rata-rata (mean) 6,4756, artinya bahwa logaritma dari total aset adalah sebesar Rp 6,4756. Dimana nilai rata-rata (mean) lebih kecil daripada nilai standar devisiasi yaitu 7,74076 yang artinya bahwa terdapat perbedaan data yang kurang bervariasi bervariasi antar perusahaan sampel.

\section{Uji Asumsi Klasik}

Uji Normalitas

[Figure 4 about here.]

Sumber : SPSS v.20 (Data yang diolah tahun 2019)

Hasil uji normalitas Gambar 4 menunjukan bahwa data tidak terdistribusi normal karena probability value $<0,05$ sehingga harus ditransformasi agar data terdistribusi secara normal. Perlakuan terhadap data yang tidak normal adalah dengan melakukan transformasi atau mengubah data ke dalam bentuk Ln (logaritma natural) untuk memperkecil skala ukuran data dan untuk menormalkan distribusi data. Hasil uji normalitas data setelah transformasi adalah sebagai berikut:

[Figure 5 about here.]

[Figure 6 about here.]

Sumber : SPSS v.20 (Data yang diolah tahun 2019)

BerdasarkanGambar 5 tersebut menunjukan bahwa nilai Kolmogorov-Smirnov adalah 0,909 dan signifikansi 0,380, nilai signifikansi tersebut jauh diatas 0,05 yang mengartikan bahwa data residual terdistribusi dengan normal, sedangkan grafik normal plot dapat dilihat pada Gambar 6 bahwa data menyebar disekitar garis diagonal dan mengikuti arah garis diagonal. Kesimpulannya adalah data dapat terdistribusi dengan normal dan model regresi dapat dipakai untuk pengujian selanjutnya.

Uji Autokorelasi

[Figure 7 about here.]

Sumber : SPSS v.20 (Data yang diolah tahun 2019)

Berdasarkan hasil regresi model summary menunjukan bahwa dalam penelitian ini tidak terdapat autokorelasi karena Menurut Sunyoto (2016:98) dalam pengambilan keputusan ada tidaknya autokorelasi dengan menggunakan Durbin Watson Test (D-W Test) Bila nilai D-W terletak diantara 2 sampai +2 berarti di indikasi tidak ada autokorelasi. Nilai 
Durbin Watson dalam penelitian ini adalah sebesar 1,594 terletak diantara -2 sampai dengan +2 . Oleh karena itu, dalam penelitian ini dapat disimpulkan bahwa tidak terdapat autokorelasi.

[Figure 8 about here.]

Berdasarkan hasil uji heteroskedastisitas pada gambar 3, menunjukan bahwa ada pola yang jelas, dimana titik-titik menyebar diatas dan dibawah angka 0 pada sumbu Y, maka dapat disimpulkan bahwa tidak terjadi heteroskedastisitas pada model regresi ini.

\section{Uji Multikolonieritas}

[Figure 9 about here.]

Berdasarkan tabel diatas dapat diketahui bahwa model tidak terdapat multikolinieritas masalah, karena VIF (variabel inflation factor) tidak lebih dari 10. VIF current ratio 4,288< 10 , VIF total asset turnover $1,041<10$, VIF debt to equity ratio $4,285<10$, dan VIF ukuran perusahaan $1,044<10$. Demikian juga nilai tolerance pada current ratio sebesar 0,233, total asset turnover 0,960, debt to equity ratio 0,233 dan ukuran perusahaan 0,958. Masing-masing variabel independen, nilai tolerance lebih besar dari 0,10 sehingga dapat disimpulkan bahwa tidak terjadi gejala multikolonieritas antara variabel independen dan model regresi dalam penelitian ini layak digunakan.

[Figure 10 about here.]

Gambar 10 maka hasil pengujian analisis regresi berganda dapat dijelaskan melalui persamaan sebagai berikut ini:

LnROA=-7,350-0,339LnCR+0,902LnTATO-0,622LnDER+2

Perasamaan regresi tersebut maknanya adalah sebagai berikut:

Berdasarkan persamaan regresi diatas besarnya koefisien regresi dari masing-masing variabel dapat diketahui bahwa nilai konstanta sebesar $-7,350$ jika variabel CR, TATO, DER dan ukuran perusahaan dianggap konstan (tetap nilainya).Variabel Current ratio menunjukan arah negatif terhadap ROA pada perusahaan manufaktur sektorindustri barang konsumsi periode 2011-2017 dengan nilai koefisien regresi sebesar $-0,339$. Tanda negatif pada koefisien menunjukan bahwa adanya penurunan Current ratio maka akan terjadi penurunan pada ROA yang dibagikan sebesar 0,339.

Variabel Total asset turnover menunjukan arah positif terhadap ROA pada perusahaan manufaktur sektor industri barang konsumsi periode 2011-2017 dengan nilai koefisien regresi sebesar 0,902 . Tanda positif pada koefisien menunjukan bahwa adanya kenaikan total asset turnover maka akan terjadi kenaikan pada ROA yang dibagikan sebesar 0,902.

Variabel Debt to equity menunjukan arah negatif terhadap ROA pada perusahaan manufaktur sektor industri barang konsumsi periode 2011-2017 dengan nilai koefisien regresi sebesar -0,622. Tanda negatif pada koefisien menunjukan bahwa adanya penurunan debt to equity maka akan terjadi kenaikan pada ROA yang dibagikan sebesar -0,622.

Variabel Size menunjukan arah positif dan terhadap ROA pada perusahaan manufaktur sektor industri barang konsumsi periode 2011-2017 dengan nilai koefisien regresi sebesar 2,537 . Tanda positif pada koefisien menunjukan bahwa adanya kenaikan size maka akan terjadi peningkatan pada ROA yang dibagikan sebesar 2,537.

\section{Hasil Uji Kelayakan Model (Godness of Fits) Uji Koefisien Determinasi}

Menurut Ghozali (2018) koefisien determinasi pada intinya mengukur seberapa jauh kemapuan model dalam menerangkan variasi variabel dependen.

[Figure 11 about here.]

Berdasarkan Gambar 11 diatas dapat dilihat hasil analisis regresi secara keseluruhan menunjukan nilai (Adjusd $R$ Square) sebesar 0,268 atau $26,8 \%$ artinya menunjukan bahwa hanya sekitar 26,8\% variabel terikat ROA yang dipengaruhi oleh variabel bebas CR, TATO, DER dan Ukuran perusahaan sementara sisanya $73,2 \%$ dijelaskan oleh variabel independen lain yang tidak diteliti dalam penelitian ini. Semakin kecil Standard Error of the Estimate (SEE) akan membuat model regresi semakin tepat dalam memprediksi variabel dependen yaitu ROA dengan variabel independennya.

Uji F

[Figure 12 about here.]

Berdasarkan Gambar 12, hasil nilai signifikannya adalah $0,000<0,05$, maka dari itu dapat dilihat dari persamaan variabel bebas yakni CR, TATO, DER dan Size secara bersamasama berpengaruh terhadap ROA pada perusahaan manufaktur sektor industri barang konsumsi periode 2011-2017. Untuk itu, penelitian dengan model regresi ini digunakan untuk analisis.

\section{Uji t}

Uji t menunjukan seberapa jauh pengaruh satu variabel penjelas atau independen secara individual dalam menerangkan variasi variabel independen.

[Figure 13 about here.]

\section{Pengaruh Current Ratio (CR) Terhadap Return on Assets (ROA)}

Berdasarkan Gambar 13 Variabel CR memiliki nilai sebesar 1,480 dengan nilai signifikansi 0,141. Nilai signifikansi lebih besar dari 0,05 menunjukan bahwa variabel CR tidak berpengaruh signifikan terhadap ROA. Dengan demilian H1 ditolak 


\section{Pengaruh Total Assets Turnover (TATO) Terhadap Return on Assets (ROA)}

Berdasarkan tabel 9 variabel TATO memiliki nilai sebesar 4,915 dengan nilai signifikansi 0,000. Nilai signifikansi lebih kecil dari 0,05 menunjukan variabel TATO berpengaruh signifikan terhadap ROA. Dengan demilian H2 diterima

\section{Pengaruh Debt to Equity Ratio (DER) Terhadap Return on Assets (ROA)}

Berdasarkan tabel 9 variabel DER memiliki nilai sebesar -3,284 dengan nilai signifikansi 0,001. Nilai Signifikansi lebih kecil dari 0,05 menunjukan variabel DER berpengaruh signifikan terhadap ROA. Dengan demilian H3 diterima

\section{Pembahasan}

Penelitian ini bertujuan untuk menguji pengaruh langsung CR, TATO, DER dan Ukuran perusahaan terhadap ROA pada perusahaan manufaktur sektor industri barang konsumsi yang terdaftar di Bursa Efek Indonesia.

\section{Pengaruh Current ratio terhadap Return on asset}

Dalam pengujian yang dilakukan, variabel current ratio terhadap return on asset dilihat berdasarkan hasilnya nilai thitung sebesar -1,586 dan nilai signifikansi adalah 0,141 dan nilai signifikasi tersebut lebih besar dari 0,05 . Hal ini mengartikan bahwa variabel current ratio tidak berpengaruh terhadap return on asset.

Hubungan antara teori signal dengan current ratio yaitu apabila nilai dari current ratio meningkat, maka ini berarti bahwa perusahaan mampu untuk mengatasi kewajiban jangka pendeknya dengan baik dan hal ini dapat dijadikan sinyal bagi pihak manajemen untuk menarik minat para investor untuk melakukan investasi pada perusahaan tersebut. Semakin tinggi angka current ratio maka semakin baik reputasi perusahaan, dan akan membuat harga saham meningkat yang nantinya secara tidak langsung akan meningkatkan return saham.

Hasil penelitian ini konsisten dengan hasil penelitian sebelumnya aji Asiah (2010); Barus (2013) dan Anggarsari dan Aji (2018) yang dalam hal ini current ratio tidak berpengaruh signifikan terhadap return on asset. Namun penelitian ini tidak konsisten dengan penelitian Putri (2018); Setiawan (2010); Raharjo (2016) bahwa Current ratio berpengaruh signifikan terhadap return on asset.

Current ratio yang rendah mengindikasi bahwa kurang asset lancar perusahaan dalam melunasi kewajiban jangka pendeknya. Akibatnya operasional perusahaan akan terganggu karena kurangnya asset lancar perusahaan sehingga dapat menurunkan profitabilitas perusahaan. Disisi lain, current ratio yang begitu tinggi juga kurang bagus karena menunjukan ketidakmampuan perusahaan dalam mengelola dana yang ada sehingga dana yang ada menganggur yang berpeluang untuk menurunkan kemampuan perusahaan dalam menghasilkan profitabilitas.

\section{Pengaruh Total asset turnover terhadap Return on asset}

Dalam pengujian yang dilakukan, variabel total asset turnover terhadap return on assety dilihat berdasarkan hasilnya nilai thitung sebesar 4,814 dan nilai signifikasinya adalah 0,000 dan nilai signifikasi tersebut lebih kecil dari 0,05 . Hal ini mengartikan bahwa variabel total asset turnover berpengaruh positif terhadap return on asset.

Hubungan teori signal dengan TATO yaitu apabila nilai dari TATO semakin tinggi, maka ini menunjukkan bahwa perusahaan telah beroperasi pada volume yang memadai bagi kapasitas investasinya. Jadi semakin tinggi aktivitas yang ada pada perusahaan berarti semakin efektif dalam mengelola aktivitas transaksi yang ada diperusahaan. Adanya tingkat efektivitas yang tinggi menunjukkan kesempatan bertumbuh perusahaan yang tinggi pada masa mendatang. Tentunya ini dapat dijadikan signal oleh para investor untuk melakukan investasi pada perusahaan-perusahaan yang memiliki prospek cerah di masa mendatang.

Hasil penelitian ini konsisten dengan hasil penelitian sebelumnya Barus (2013), Yuniarta (2015) menyatakan bahwa Total asset turnover berpengaruh signifikan terhadap return on asset. Namun hasil penelitian ini tidak konsisten dengan penelitian Setiawan (2010); Sari (2014) yang dalam hal ini total asset turnover tidak berpengaruh dan signifikan terhadap return on asset.

Menurut Wardiyah (2017) semakin besar rasio ini, semakin baik yang berarti aktiva dapat lebih cepat berputar dan meraih laba yang menunjukan semakin efisiensi penggunaan keseluruhan aktiva dalam menghasilkan penjualan. Dengan kata lain jumlah aset yang sama dapat memperbesar volume penjualan apabila asset turnover ditingkatkan atau diperbesar.Semakin tinggi total asset turnover berarti semakin efisien penggunaan keseluruhan aset dalam menghasilkan penjualan. Jumlah aset yang sama dapat memperbesar volume penjualan apabila total asset tiurnover ditingkatkan atau diperbesar, sehingga apabila volume penjualan besar dan laba yang diperoleh semakin tinggi.

\section{Pengaruh Debt to equity terhadap Return on asset}

Dalam pengujian yang dilakukan, variabel debt to equity ratio terhadap return on assety dilihat berdasarkan hasilnya nilai thitung sebesar -3,207 dan nilai signifikansi adalah 0,001 dan nilai probabilitas tersebut lebih kecil dari 0,05 . Hal ini mengartikan bahwa variabel debt to equity ratio berpengaruh negatif terhadap return on asset.

Hubungan teori signal dengan DER yaitu apabila nilai dari DER tinggi, maka ini menunjukkan bahwa perusahaan memiliki hutang yang besar dan semakin tinggi pula resiko yang ditanggung perusahaan. Selama ekonomi sulit atau suku bunga tinggi, perusahaan dengan DER yang tinggi dapat mengalami masalah keuangan. Hal ini dapat menurunkan profitabilitas perusahaan dan ini dapat dijadikan signal untuk investor untuk tidak melakukan investasi pada perusahaan yang sedang men- 
galami situasi seperti ini.

Hasil penelitian ini konsisten dengan hasil penelitian sebelumnya , Sari (2014); Raharjo (2016) bahwa Debt to equity berpengaruh signifikan terhadap return on asset. Namun hasil penelitian ini tidak konsisten dengan penelitian Setiawan (2010); Putri (2018); Barus (2013) yang dalam hal ini Debt to equity ratio tidak berpengaruh dan signifikan terhadap return on asset.

Menurut Kasmir (2016) apabila Debt to Equity Ratio (DER) meningkat maka laba yang akan dihasilkan akan menurun (tidak menguntungkan), karena semakin besar Debt to Equity Ratio (DER) juga menunjukan proporsi modal sendiri yang rendah untuk membiayai aktivanya.

Pengaruh Ukuran Perusahaan terhadap Return on asset

Dalam pengujian yang dilakukan, variabel Ukuran perusahaan (size) terhadap return on assety dilihat berdasarkan hasilnya nilai t-hitung sebesar 4,524 dan nilai probabilitasnya adalah 0,000 dan nilai probabilitas tersebut lebih kecil dari 0,05. Hal ini mengartikan bahwa variabel ukuran perusahaan (size) berpengaruh positif terhadap return on asset.

Hubungan teori sinyal dengan ukuran perusahaan yaitu semakin besar perusahaan maka akan semakin besar pula aset yang dimiliki, jika aset semakin besar maka dana yang digunakan juga semakin besar untuk operasional, dengan semakin besar operasional maka cenderung berdampak pada pendapatan juga akan semakin besar yang tentu di ikuti oleh pergerakan dari laba perusahaan. Pergerakan laba inilah yang pasti akan menggerakan return on asset perusahaan. Hal ini dapat dijadikan sinyal oleh investor untuk melakukan investasi pada perusahaan yang memiliki ukuran aset yang besar. Oleh karena itu ukuran perusahaan berpengaruh terhadap return on asset.

Hasil penelitian ini konsisten dengan hasil penelitian sebelumya Barus (2013); Putri (2018) bahwa Ukuran perusahaan (size) berpengaruh signifikan terhadap return on asset. Namun hasil penelitian ini tidak konsisten dengan penelitian Setiawan (2010); Sari (2014) Raharjo (2016) yang dalam hal ini Ukuran perusahaan (Size) tidak berpengaruh dan signifikan terhadap return on asset

Perusahaan dengan aset yang besar maka penggunaan sumber dana yang ada bisa digunakan secara maksimal dan efisien untuk memperoleh keuntungan usaha yang maksimal dan perusahaan dengan aset yang kecil tentu akan menghasilkan keuntungan sesuai dengan aset yang relatif kecil. Selain itu jika jumlah asset yang dimiliki oleh perusahaan besar maka akan menunjukkan kualitas serta kinerja yang baik dari perusahaan tersebut. Semakin besar aktivayang dimiliki perusahaan menunjukkan semakin tinggi profit yang dihasilkan (Ardiansyah, 2017).

\section{Pengaruh Current Ratio (CR), Total Asset Turnover (TATO), Debt to Equity Ratio (DER) dan Ukuran Perusahaan (Size) terhadap Return on asset}

Hasil pengujian menunjukan bahwa Current Ratio (CR), Total Asset Turnover (TATO), Debt to Equity Ratio (DER) dan
Ukuran Perusahaan (Size) secara bersama-sama (simultan) berpengaruh signifikan terhadap return on asset (ROA).

Hal ini ditunjukan dengan nilai signifikansi $F=0,000$ (lebih kecil dari 0,05) pada pengujian uji simultan (uji F). Hasil penelitian ini sejalan dengan penelitian Barus dan Leliani (2013) dan Wijayanto dan Suhendro (2018) yang menunjukan bahwa CR,TATO,DER dan SIZE berpengaruh signifikan terhadap ROA.

\section{KESIMPULAN}

Pada penelitian ini disimpulkan bahwa Current ratio (CR) tidak berpengaruh terhadap Return On Asset (ROA), Total asset turnover (TATO) dan Ukuran Perusahaan (Size) berpengaruh positif signifikan terhadap Return On Asset (ROA) dan Debt to equity ratio (DER) berpengaruh negatif signifikan terhadap Return On Asset (ROA) pada perusahaan manufaktur sektor industri barang konsumsi. Pada penelitian ini disimpulkan bahwa Current Ratio, Total Asset Turnover, Debt to Equity Ratio dan Ukuran perusahaan secara bersama-sama (simultan) berpengaruh terhadap Return on Asset pada perusahaan manufaktur sektor industri barang konsumsi.

\section{PENDANAAN}

Penelitian ini menggunakan dana mandiri dari peneliti.

\section{UCAPAN TERIMA KASIH}

Peneliti menyadari sepenuhnya, tanpa bimbingan dari berbagai pihak, Tugas Akhir Skripsi ini tidak akan dapat diselesaikan dengan baik dan benar. Oleh karena itu, pada kesempatan ini penulis ingin menyampaikan rasa terima kasih kepada:

1. Dr. Mukhaer Pakkanna, SE., MM. selaku Rektor Institut Teknologi dan Bisnis Ahmad Dahlan Jakarta.

2. Sutia Budi, SE, M.Si. selaku Dekan Institut Teknologi dan Bisnis Ahmad Dahlan Jakarta

3. Taryana, SE, M.Si. selaku Ketua Jurusan Akuntansi Institut Teknologi dan Bisnis Ahmad Dahlan Jakarta

4. Dr. Iwan Setiadi, SE., M.Si. Dosen Pembimbing yang telah meluangkan waktu dan dengan sabar memberikan bimbingan serta pengarahan selama penyusunan skripsi

5. Segenap Dosen Institut Teknologi dan Bisnis Ahmad Dahlan Jakarta yang telah memberikan ilmu bermanfaat selama penulis menimba ilmu.

6. Keluargaku, terima kasih atas doa, cinta dan kasih sayang kalian yang sudah memberikan semangat dan motivasi untuk penulis. 


\section{REFERENCES}

Agha, H. (2014). Impact of Working Capital Management on Profitability. Europen Scientific Journal 10, 1857-7881.

Asiah, H. (2010). Analisis Faktor - faktor yang mempengaruhi Profitbilitas (Studi Empiris Pada Perusahaan Manufaktur di BEI Periode. Jurnal Spread 7.

Azhari, R. (2016). Pengaruh ROE, DER, TATO, dan PER terhadap Harga Saham Perusahaan Properti dan Real Estate yang go publik di Bursa Efek Indonesia. Jurnal Administrasi Bisnis (JAB)|Vol 32.

Barus, L. (2013). Analisis Faktor - faktor yang mempengaruhi Profitabilitas Pada Perusahaan Manufaktur yang Terdaftar di Bursa Efek Indonesia. Jurnal Wira Ekonomi Mikroskil 3.

Brigham, E. F. and Houston, J. F. D. (2013). Dasar-Dasar Manajemen Keuangan. Buku 2, 11 edn. (Jakarta: Salemba Empat).

Ghozali, I. (2018). Aplikasi Analisis Multivariate dengan Program IBM SPSS 25 (Semarang: Penerbit Universitas Diponegoro).

Hartono, J. (2010). Teori Portofolio dan Analisis Investasi (Yogyakarta: BPFE), 280.

Kasmir (2016). Analisis Laporan Keuangan (Jakarta: PT. RajaGrafindo Persada).

Meithasari (2017). Analisis faktor-faktor yang mempengaruhi profitabilitas.

Putri, N. (2018). Pengaruh Likuiditas, Solvabilitas, Aktivitas, Dan Ukuran Perusahaan Terhadap Profitabilitas(Studi Empiris Pada Perusahaan Makanan dan Minuman yang Terdaftar di BEI Tahun.

Raharjo, A. (2016). Ukuran perusahaan dan Umur perusahaan terhadap Profitabilitas perusahaan manufaktur yang terdaftar di Bursa Efek Indonesia Tahun 20102014. Journal Of Accounting 2.

Sari, B. (2014). Pengaruh Debt to Equity Ratio. Firm Size, Inventory Turnover dan Asset Turnover pada Profitabilitas. E-Jurnal Akuntansi Universitas Udayana 6.2. Hal, 261-273.

Setiawan, E. (2010). Pengaruh Current Ratio, Inventory Turnover, Debt To Equity Ratio, Total Asset Turnover, Sales, Dan Firm SizeTerhadap Roa Pada Perusahaan Food And Beverage Yang Terdaftar Di Bursa Efek Indonesia (BEI) Periode 20102013. Jurnal Ekonomi.
Subramanyam, K. R. and Wild, J. J. (2013). Analisis Laporan Keuangan. Edisi 10., and others (ed.). Kedua edn. (Jakarta: Salemba Empat).

Sudana, M. (2011). Manajemen Keuangan Perusahaan (Erlangga, Jakarta).

Sugiyono (2016). Metode Penelitian Pendidikan Pendekatan Kuantitatif (Kualitatif, dan R\&D. Bandung: Alfabeta).

Sujarweni, V. W. (2017). Analisis Laporan Keuangan (Yogyakarta: Pustaka Baru Press).

T., P. A. and Mawardi, W. (2016). Analisis Pengaruh Struktur Modal, Profitabilitas, Likuiditas, kebijakan Deviden, Sales Growth dan Ukuran Perusahaan Terhadap Nilai Perusahaan.

Wardiyah, L. M. (2017). Analisis Laporan Keuangan. Cetakan I (CV Pustaka Setia).

Wijayanto, S. (2018). Pengaruh current ratio, debt to equity ratio, total asset turnover dan size terhadap return on asset. Jurnal Ekonomi Paradigma 19.

Yuniarta, S. (2015). Pengaruh Modal Kerja, Likuiditas, Aktivitas dan Ukuran Perusahaan Terhadap Profitabilitas Pada Perusahaan Manufaktur yang Terdaftar di Bursa Efek Indonesia. E-Jurnal S1 Ak Universitas Pendidikan Ganesha Jurusan Akuntansi Program S1. E-Jurnal S1 Ak Universitas Pendidikan Ganesha Jurusan Akuntansi Program S1 3.

Conflict of Interest Statement: The authors declare that the research was conducted in the absence of any commercial or financial relationships that could be construed as a potential conflict of interest.

Copyright (C) 2020 and. This is an open-access article distributed under the terms of the Creative Commons Attribution License (CC BY). The use, distribution or reproduction in other forums is permitted, provided the original author(s) and the copyright owner(s) are credited and that the original publication in this journal is cited, in accordance with accepted academic practice. No use, distribution or reproduction is permitted which does not comply with these terms. 


\section{LIST OF FIGURES}

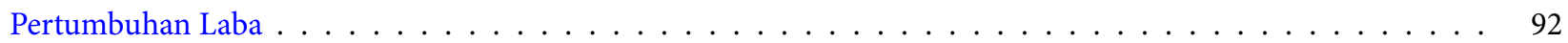

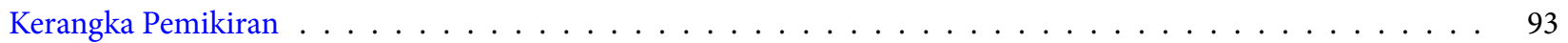

Analisis Deskriftif Statistik . . . . . . . . . . . . . . . . . . . . . . . . . . . . . . . 94

Hasil pengujian Normalitas sebelum Transformasi . . . . . . . . . . . . . . . . . . . . . . 95

Hasil pengujian Normalitas setelah transformasi . . . . . . . . . . . . . . . . . . . . . 96

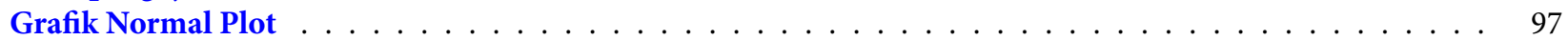

Durbin Watson Test . . . . . . . . . . . . . . . . . . . . . . . . . . . . 98

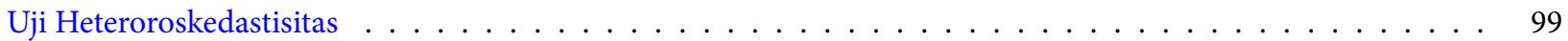

Uji Multikolonieritas . . . . . . . . . . . . . . . . . . . . . . . . . . . . 100

Hasil Perhitungan Regresi . . . . . . . . . . . . . . . . . . . . . . . . . 101

Hasil Uji Koefisien Determinasi . . . . . . . . . . . . . . . . . . . . . . . . . . . . . 102

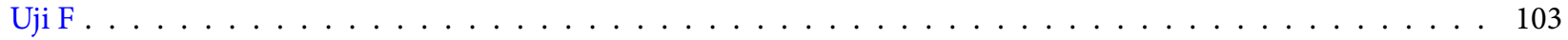

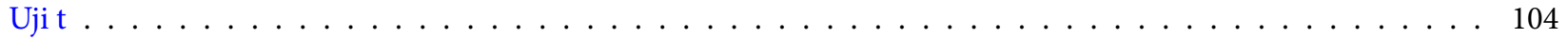




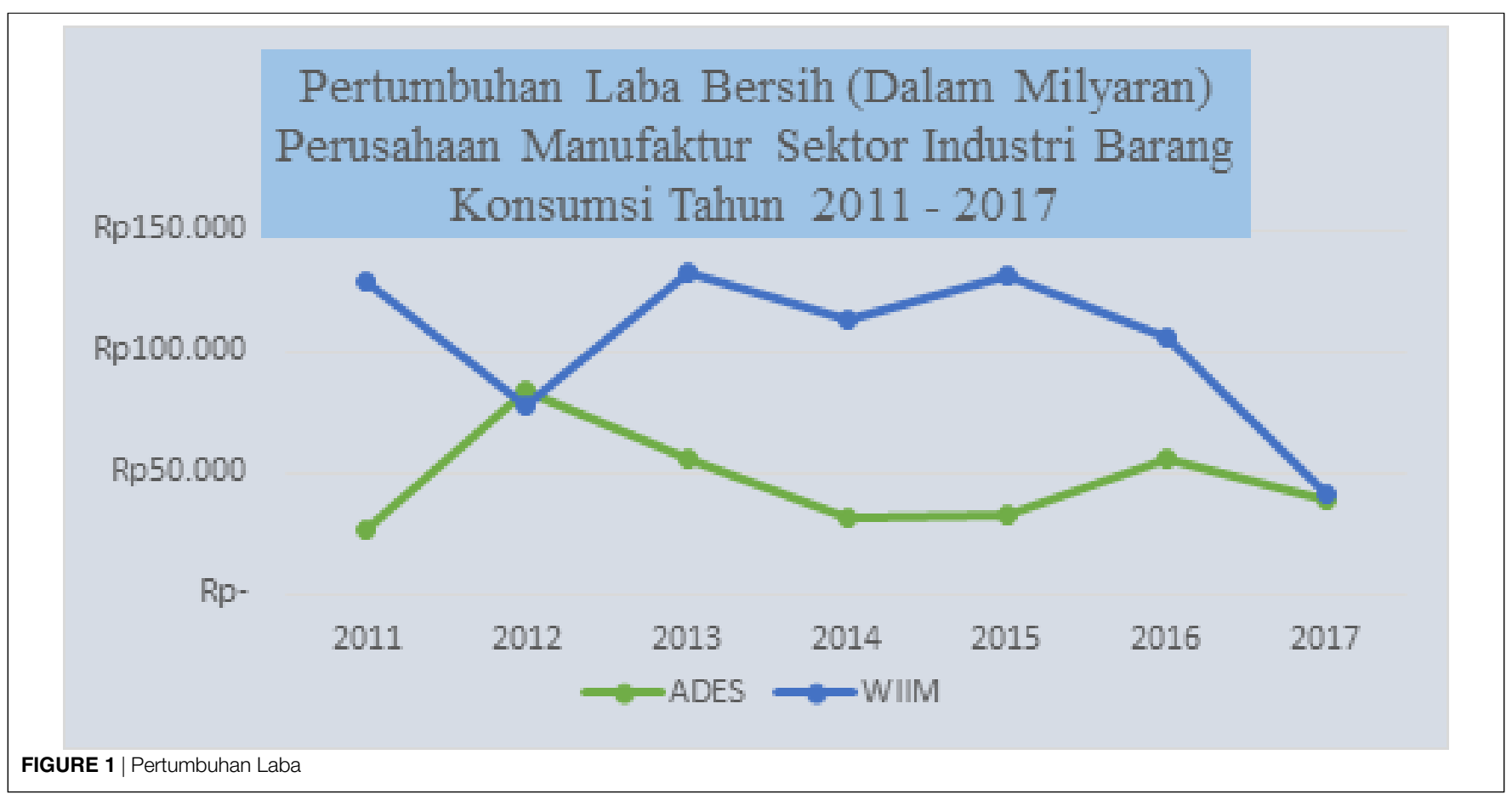




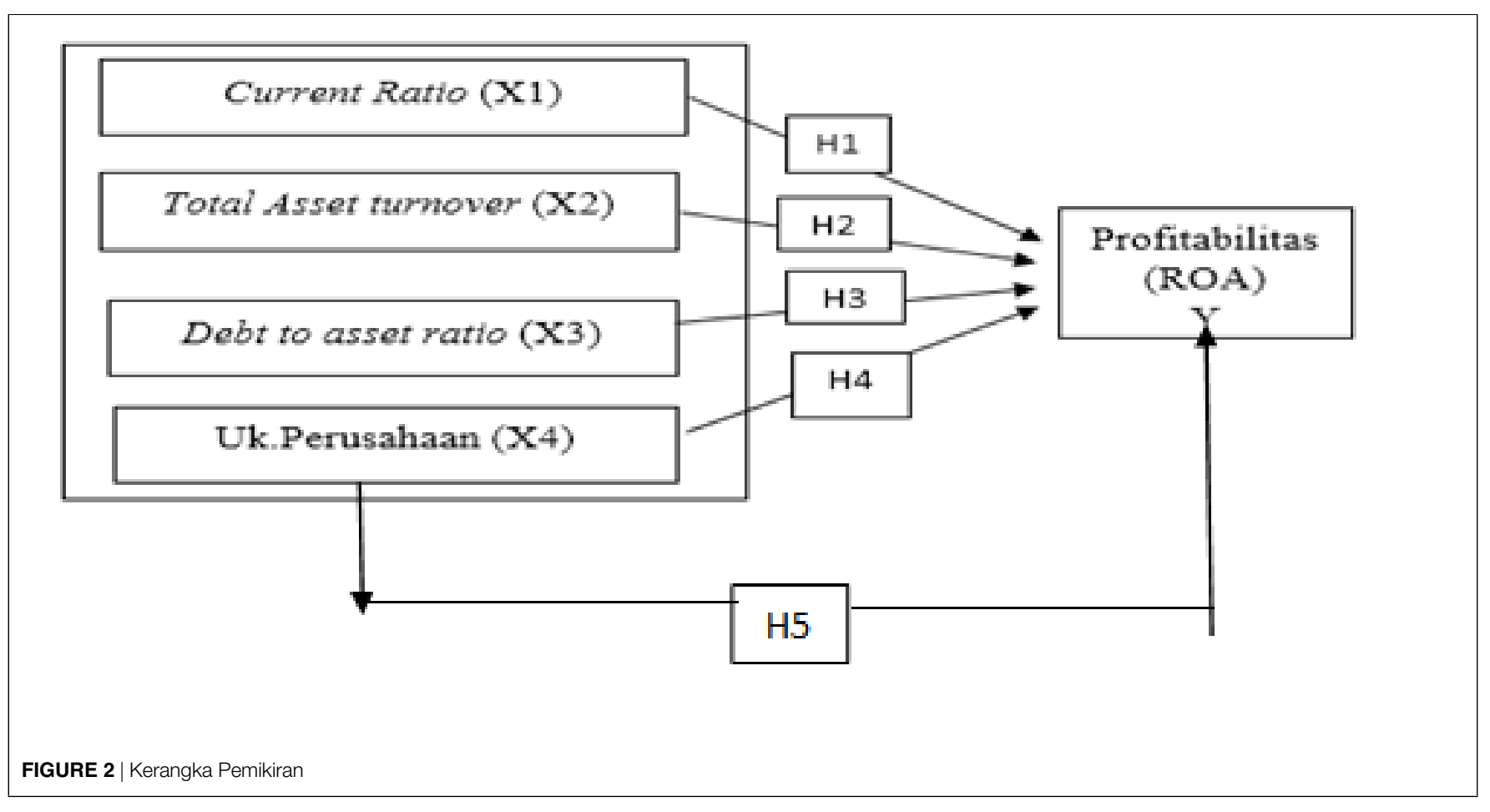




\section{Descriptive Statistics}

\begin{tabular}{|l|r|r|r|r|r|}
\hline & \multicolumn{1}{|c|}{$\mathrm{N}$} & Minimum & Maximum & \multicolumn{1}{c|}{ Mean } & Std. Deviation \\
\hline Y=ROA & 140 &, 0022 &, 6572 &, 128212 &, 1095982 \\
X1=CR & 140 &, 5139 & 11,7429 & 2,638806 & 1,7325072 \\
X2=TATO & 140 &, 5463 & 3,3974 & 1,388571 &, 5646997 \\
X4=DER & 140 &, 1165 & 2,4926 &, 808873 &, 5228834 \\
X4=SIZE & 140 & 5,0720 & 7,9630 & 6,474059 &, 7405306 \\
Valid N (listwise) & 140 & & & & \\
\hline
\end{tabular}

FIGURE 3 | Analisis Deskriftif Statistik 


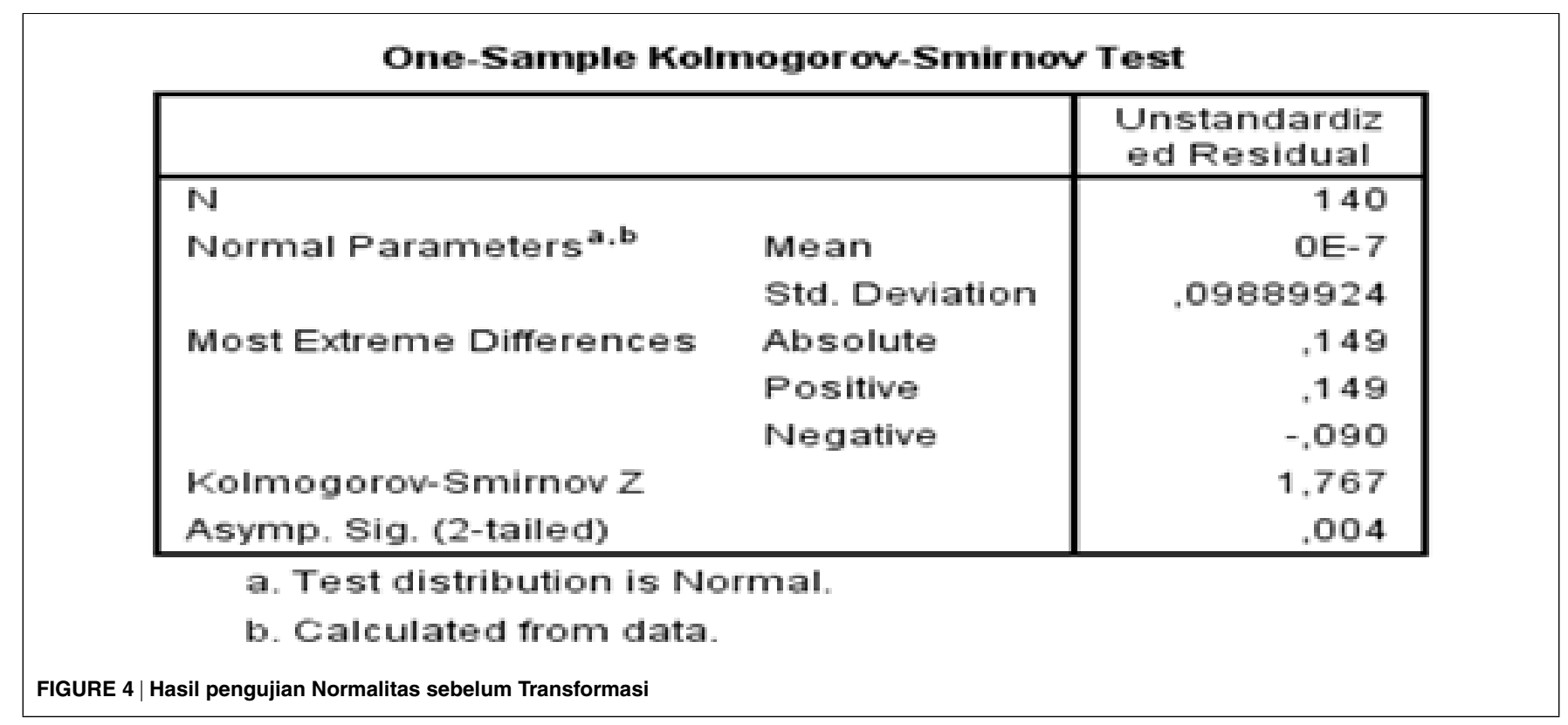




\begin{tabular}{|c|c|c|}
\hline \multicolumn{3}{|c|}{ One-Sample Kolmogorow-Smirnow Test } \\
\hline & & $\begin{array}{l}\text { Unstandardiz } \\
\text { ed Residual }\end{array}$ \\
\hline $\mathrm{N}$ & & 140 \\
\hline \multirow{2}{*}{ Normal Parameters ${ }^{a \cdot b}$} & Mean & $O E-7$ \\
\hline & Std. Deviation & .75039099 \\
\hline \multirow[t]{3}{*}{ Most Extreme Differences } & Absolute & .077 \\
\hline & Positive & .077 \\
\hline & Negative & -.074 \\
\hline Kolmogorov-Smirnov $z$ & & .909 \\
\hline Asymp. Sig. (2-tailed) & & .380 \\
\hline $\begin{array}{l}\text { a. Test distribution is } N \\
\text { b. Calculated from data }\end{array}$ & mal. & \\
\hline
\end{tabular}




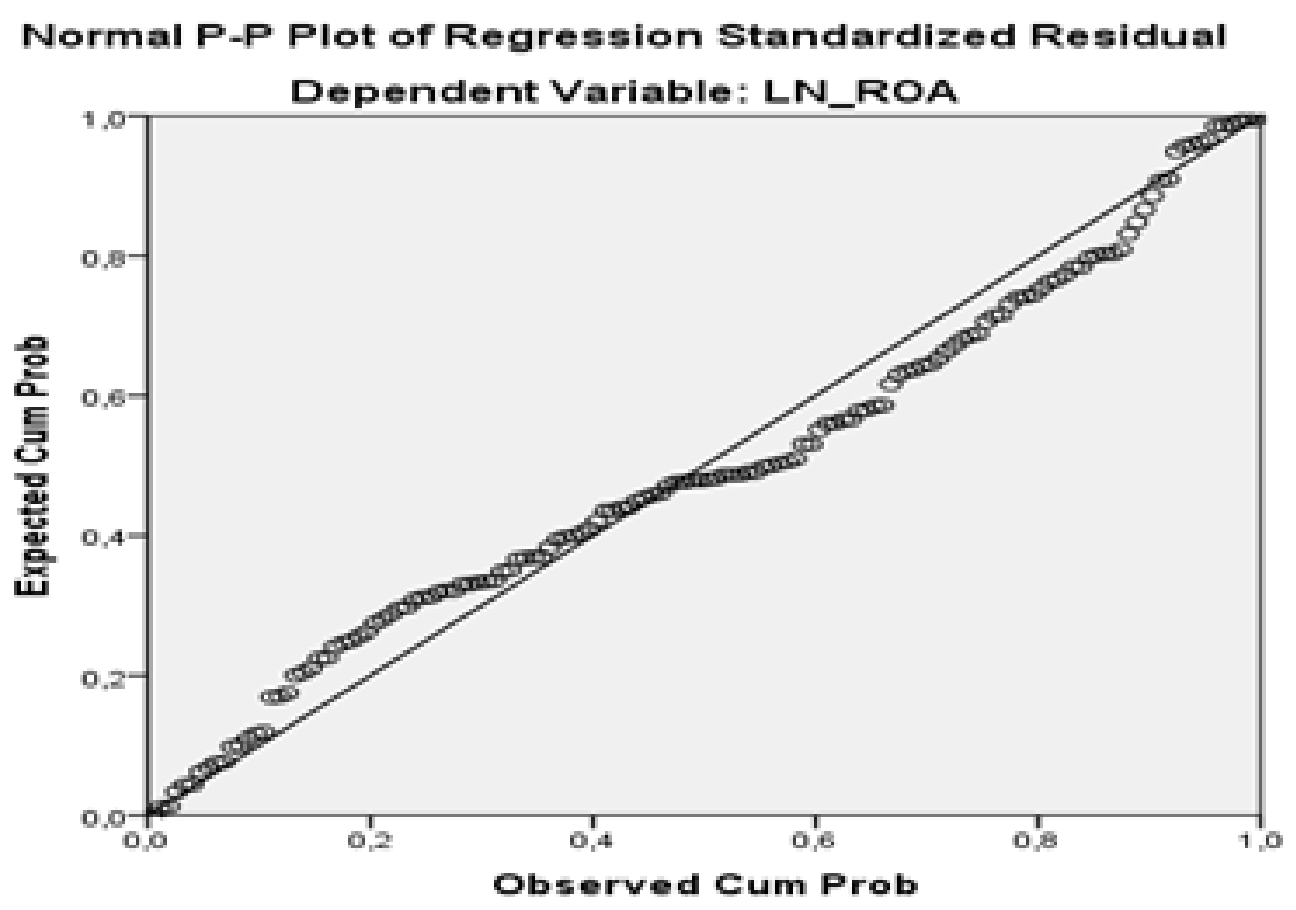

FIGURE 6 | Grafik Normal Plot 


\begin{tabular}{|l|r|r|c|c|c|}
\hline Model & R & R Square & $\begin{array}{c}\text { Adjusted R } \\
\text { Square }\end{array}$ & $\begin{array}{c}\text { Std. Error of } \\
\text { the Estimate }\end{array}$ & $\begin{array}{c}\text { Durbin- } \\
\text { Watson }\end{array}$ \\
\hline 1 &, $538^{\text {a }}$ &, 289 &, 268 &, 76143 & 1,594 \\
\hline
\end{tabular}
a. Predictors: (Constant), LN_SIZE, LN_DER, LN_TATO, LN_CR
b. Dependent Variable: LN_ROA
FIGURE 7 | Durbin Watson Test




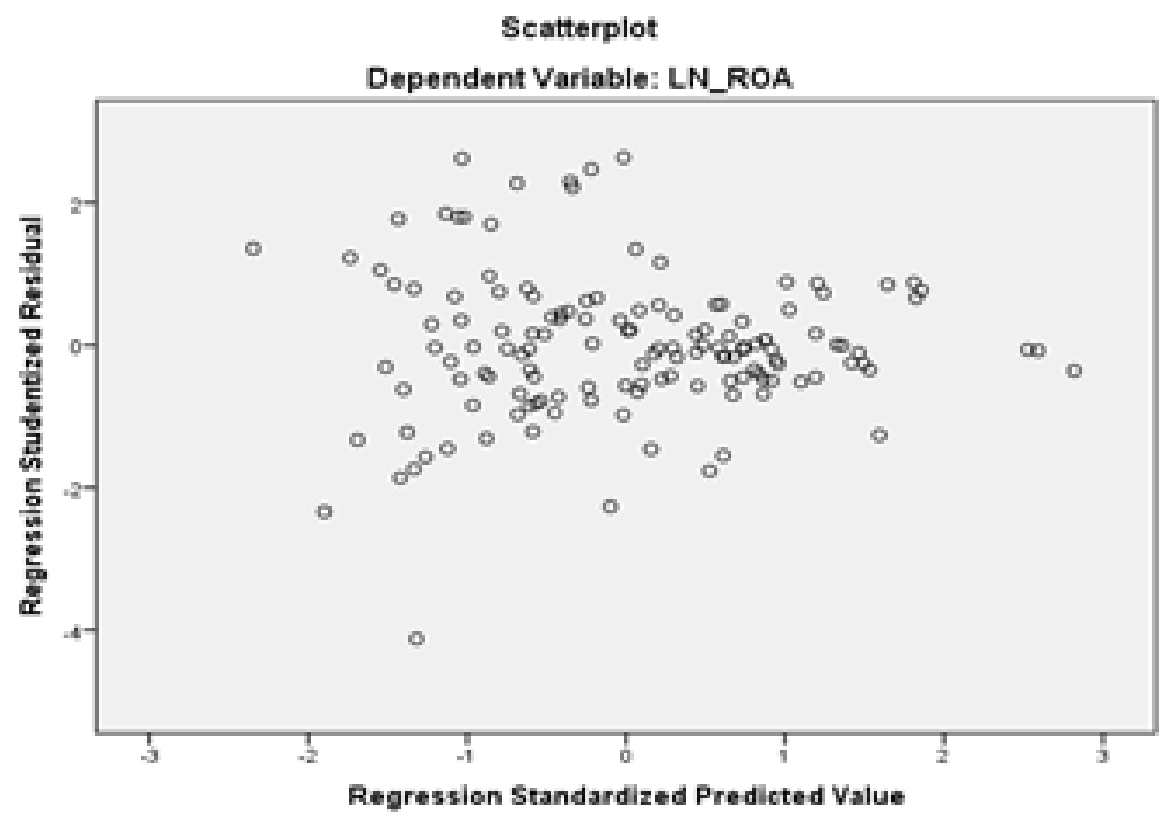

FIGURE 8 | Uji Heteroroskedastisitas 


\begin{tabular}{|c|c|c|c|c|c|c|c|c|}
\hline \multicolumn{9}{|c|}{ Coefficients $^{2}$} \\
\hline \multirow{2}{*}{\multicolumn{2}{|c|}{ Model }} & \multicolumn{2}{|c|}{ Unstandardized Coefficients } & \multirow{2}{*}{$\begin{array}{c}\begin{array}{c}\text { Standardized } \\
\text { Coefficients }\end{array} \\
\text { Beta }\end{array}$} & \multirow[b]{2}{*}{$t$} & \multirow[b]{2}{*}{ Sig. } & \multicolumn{2}{|c|}{ Collinearity Statistics } \\
\hline & & B & Std. Error & & & & Tolerance & MF \\
\hline \multirow[t]{5}{*}{1} & (Constant) & $-7,350$ & 1,092 & & $\cdot 6,731$ &, 000 & & \\
\hline & LN_CR &,- 339 & .229 &,- 222 & $-1,480$ &, 141 &, 233 & 4,288 \\
\hline & LN_TATO & ,902 & 183 &, 364 & 4,915 &, 000 &, 960 & 1,041 \\
\hline & LN_DER &,- 622 & 189 &,- 493 & $-3,284$ &, 001 &, 233 & 4,285 \\
\hline & LN_SIZE & 2,537 & .581 & 324 & 4,366 &, 000 & .958 & 1,044 \\
\hline \multicolumn{9}{|c|}{ a. Dependent Variable: LN_ROA } \\
\hline
\end{tabular}




\begin{tabular}{|c|c|c|c|c|c|c|c|c|}
\hline \multicolumn{9}{|c|}{ Coefficients $^{3}$} \\
\hline & & \multicolumn{2}{|c|}{ Unstandardized Coefficients } & $\begin{array}{l}\text { Standardized } \\
\text { Coefficients }\end{array}$ & \multirow[b]{2}{*}{$t$} & \multirow[b]{2}{*}{ Sig. } & \multicolumn{2}{|c|}{ Collinearity Statistics } \\
\hline \multicolumn{2}{|c|}{ Model } & B & Std. Error & Beta & & & Tolerance & VF \\
\hline \multirow[t]{5}{*}{1} & (Constant) & $\cdot 7,350$ & 1,092 & & $-6,731$ &, 000 & & \\
\hline & LN_CR & $\cdot, 339$ & 229 & -222 & $-1,480$ & ,141 & .233 & 4,288 \\
\hline & LN_TATO &, 902 &, 183 &, 364 & 4,915 &, 000 & 960 & 1,041 \\
\hline & LN_DER & -622 & 189 & $;, 493$ & $-3,284$ &, 001 & .233 & 4,285 \\
\hline & LN_SIZE & 2,537 & .581 & 324 & 4,366 & ,000 & 958 & 1,044 \\
\hline
\end{tabular}




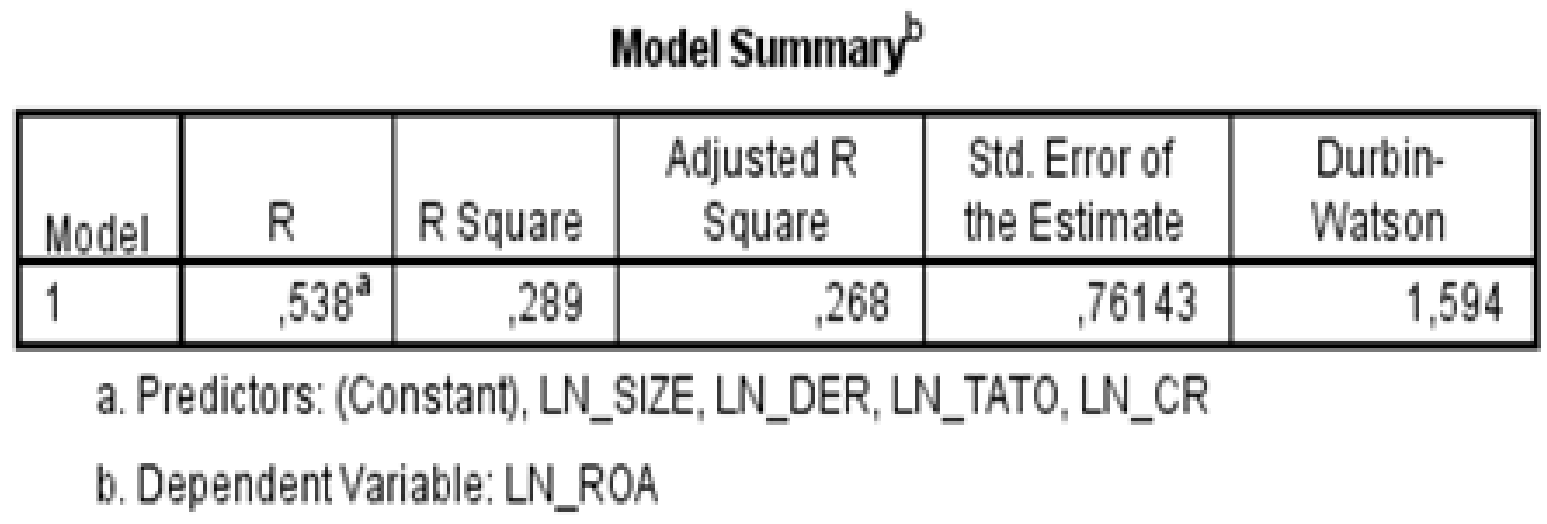

FIGURE 11 | Hasil Uji Koefisien Determinasi 


\begin{tabular}{|c|c|c|c|c|c|c|}
\hline \multicolumn{7}{|c|}{ ANOVA ${ }^{a}$} \\
\hline & & $\begin{array}{l}\text { Sum of } \\
\text { Squares }\end{array}$ & df & Mean Square & $\mathrm{F}$ & Sig. \\
\hline \multirow[t]{3}{*}{1} & Regression & 31,833 & 4 & 7,958 & 13,727 &, $000^{6}$ \\
\hline & Residual & 78,269 & 135 &, 580 & & \\
\hline & Total & 110,102 & 139 & & & \\
\hline
\end{tabular}

a. Dependent Variable: LN_ROA

b. Predictors: (Constant), LN_SIZE, LN_DER, LN_TATO, LN_CR

FIGURE 12 | Uji F 


\begin{tabular}{|c|c|c|c|c|c|c|c|c|}
\hline \multicolumn{9}{|c|}{ Coefficients $^{\mathrm{a}}$} \\
\hline & & \multicolumn{2}{|c|}{ Unstandardized Coefficients } & $\begin{array}{l}\text { Standardized } \\
\text { Coefficients }\end{array}$ & \multirow[b]{2}{*}{$t$} & \multirow[b]{2}{*}{ Sig. } & \multicolumn{2}{|c|}{ Collinearity Statistics } \\
\hline \multicolumn{2}{|c|}{ Model } & 8 & Std. Error & Beta & & & Tolerance & UF \\
\hline \multirow[t]{5}{*}{1} & (Constant) & $-7,350$ & 1,092 & & $.6,731$ &, 000 & & \\
\hline & LN_CR &,- 339 &, 229 &,- 222 & $-1,480$ & ,141 & .233 & 4,288 \\
\hline & LN_TATO &, 902 & , 183 &, 364 & 4,915 &, 000 & 960 & 1,041 \\
\hline & LN_DER & -622 & , 189 & $;, 493$ & $-3,284$ &, 001 & .233 & 4,285 \\
\hline & LN_SIZE & 2,537 &, 581 & 324 & 4,366 &, 000 &, 958 & 1,044 \\
\hline \multicolumn{9}{|c|}{ a. DependentVariable: LN_ROA } \\
\hline
\end{tabular}

